\title{
Hypoxia tolerance studies for yield, fiber and physiological traits in cotton (Gossypium hirsutum L.)
}

\author{
HUSSAIN Altaf ${ }^{1}$, FAROOQ Jehanzeb ${ }^{2 *}$, AHMAD Saghir ${ }^{3}$, MAHMOOD Abid ${ }^{4}$, SADIQ M. Attiq ${ }^{1}$, ZAFAR Ullah Zafar ${ }^{5}$ \\ and ATHAR Habib-Ur-Rehman ${ }^{5}$
}

\begin{abstract}
Background: Hypoxia tolerance studies in cotton are very rare in Pakistan. Unpredicted and excessive rainfalls result in severe losses to cotton crop in many regions of the country due to lack of hypoxia tolerance in current cotton varieties. The genotypes that can tolerate flooding are not reported earlier. The studies were conducted to explore hypoxia tolerance in local germplasm which will help to develop hypoxia tolerant cotton varieties.

Method: An experiment with randomized complete blocks was designed to study the hypoxia tolerance in different cotton varieties. The genotypes were given two treatments i.e., water logged and non-water logged conditions.

Results: The genotypes showed significant variability for yield, fiber and physiological traits. The hypoxia studies revealed that there is significant reduction for plant height in water sensitive genotype LRA-5166. The genotype $\mathrm{MNH}-786$ showed better yield and MNH-556 showed superior ginning outturn percentage under water logged conditions. Staple length, strength and micronaire values also decreased under hypoxia. Similar pattern of negative effects were observed for Chlorophyll a, b contents and chl a/b ratio. Two hypoxia tolerant cultivars CIM-573 and MNH-564 had significantly higher chlorophyll a $(1.664,1.551)$ than other cultivars under both normal and waterlogged conditions. There was a significant decrease in total free amino acids in all genotypes/cultivars due to waterlogging. Free amino acid contents were significantly higher in two waterlogging sensitive cultivars, CEDIX and N-KRISHMA, than other cultivars under both non-waterlogged and waterlogged conditions. Waterlogging caused a significant reduction in shoot soluble proteins and increase in shoot proline. The genotype LRA-5166 was the highest in shoot soluble proteins content and showed significant decrease in shoot proline.
\end{abstract}

Conclusions: With respect to yield $\mathrm{MNH}-786$ showed better results and regarding ginning outturn percentage MNH-556 exhibited superior performance. The genotypes CIM-573 and MNH-564 showed higher chlorophyll a values. The above said genotypes may be exploited for further studies related to hypoxia tolerance.

Keywords: Hypoxia, Proline content, Cotton, Chlorophyll, Physiology, Tolerance

\footnotetext{
* Correspondence: jehanzeb1763@hotmail.com

${ }^{2}$ Cotton Research Station, Ayub Agricultural Research Station, Faisalabad,

Pakistan

Full list of author information is available at the end of the article
}

(C) The Author(s). 2018 Open Access This article is distributed under the terms of the Creative Commons Attribution 4.0 International License (http://creativecommons.org/licenses/by/4.0/), which permits unrestricted use, distribution, and reproduction in any medium, provided you give appropriate credit to the original author(s) and the source, provide a link to the Creative Commons license, and indicate if changes were made. The Creative Commons Public Domain Dedication waiver (http://creativecommons.org/publicdomain/zero/1.0/) applies to the data made available in this article, unless otherwise stated. 


\section{Background}

Cotton production all over the world is affected by both biotic and abiotic factors (Salman et al. 2016). Among them flooding stress is an important abiotic stress causing substantial crop losses world-wide (Voesenek and BaileySerres 2013) and it may increase up to $80 \%$ yield losses (Shaw et al. 2013). It is a major constraint to cotton production in countries like India, Pakistan and China (Voesenek and Bailey-Serres 2013; Zhou 2010). Partial to complete water logging stress is injurious to most of crops or it may even cause premature death (Bailey-Serres and Voesenek 2008; Blom and Voesenek 1996). Growth inhibition under partial or complete flooding has been reasoned to injurious effects of flooding various biochemical and physiological processes such as respiration, photosynthesis and growth which results in necrosis and ultimately plant death (Dodd et al. 2013). The early senescence of leaves and growth inhibition in plants which subjected to flooding stress are mainly due to inhibition of nitrogen $(\mathrm{N})$ and $\mathrm{K}^{+}$uptake (Shabala et al. 2014).

Due to existence of genetic variability for flooding tolerance in plants, various morphological traits can be used to identify and select flooding tolerant plants. For example, leaf chlorosis after flooding is one of the major indices used by researchers in different crops, such as in wheat (Boru et al. 2001; Cai et al. 1996) and barley (Hamachi et al. 1990; Pang et al. 2004).

In addition to flooding induced changes in soil characteristics, it adversely affects growth and plant metabolism. Various physiological and biochemical effects of flooding include changes in respiratory metabolism, root permeability, water and mineral uptake, nitrogen fixation, and endogenous hormone (Shabala et al. 2014).

In view of this information, selection of crop cultivars with considerable tolerance to waterlogging stress has been considered a very useful means of utilizing waterlogged areas particularly those areas where short-term flooding occurs frequently due to heavy rain falls or casual floods (Zhou 2010). From our previous studies, eight cotton genotypes/cultivars viz., MNH-564, FH-114, MNH-786 and CIM-573 (waterlogging tolerant) and N-KRISHMA, LRA-5166, CEDIX and H-142 (waterlogging sensitive), were selected out of 60 cultivars/genotypes of cotton at three different growth stages, i.e. seedlings, flowering and boll formation, under field waterlogged conditions (Hussain et al. 2014). The aim of this study was to investigate the physiological responses of selected cotton genotypes to flooding stress. Moreover, it was assessed that which physiological characteristic of cotton cultivars can be used as physiological indicator for flooding tolerance.

\section{Methods}

The experiment was conducted in the Department of Agricultural Research, Cotton Research Station, Multan, Pakistan $\left(30^{\circ} 11^{\prime} \mathrm{N}\right.$ and $\left.71^{\circ} 28^{\prime} \mathrm{E}\right)$ during the midweek of May, 2011. The eight cotton genotypes/cultivars/accessions including four tolerant genotypes, MNH-564, FH-114, MNH-786, and CIM-573, and four sensitive genotypes viz., N-KRISHMA, LRA-5166, CEDIX, and $\mathrm{H}-142$, were selected from the screening experiment. The two treatments, i.e., water logged and non-water logged conditions, were exploited in the experiment using randomized complete block design. The main plot comprised of 48 subplots (both control and waterlogging). The area of each subplot was $7.0 \times 1.50$ square meters. The inter-row and inter-plant distances were maintained at $75 \mathrm{~cm}$ and $30 \mathrm{~cm}$, respectively. Two seeds per hole were sown with hand and later thinned to one seedling per hole after emergence when the seedlings attained 3 5 true leaves $(25 \sim 30 \mathrm{~d})$ after the sowing. All other agronomic and cultural practices were kept normal including fertilization, insects pests management, and weeding were maintained accordingly accept irrigation of water logged condition treatment experiment. There is a significant decrease of physio-chemical characteristics of the soil before and after the flooding in electrical conductivity (EC), and $\mathrm{pH}$ of the soil saturated paste. The irrigation was applied for 14 days up to the stage when there was no further leaching downword or horizontally. The source of irrigation was turbine water. The redox potential of the soil was also recorded three times in a day for 14 days, which changed from $470 \pm$ $3.5 \mathrm{mV}$ to $-41 \pm 1.93 \mathrm{mV}$. Metrological data including maximum and minimum temperatures from May to November were recorded and the highest temperature during June and minimum during November were $46.2^{\circ} \mathrm{C}$ and $29.3^{\circ} \mathrm{C}$, respectively. Samples/specimens of shoot and root were taken for physiological, quantitative and qualitative parameters from ten guarded plants at the flowering stage both from flooded and un-flooded fields. Seed cotton (lint) of the plant was picked in separate kraft paper bags for fiber quality parameter analysis.

\section{Seed cotton yield per plant}

Opened bolls from the selected five consecutive plants were picked separately in a craft paper bag and weighed seed cotton yield per plant and calculated the average of 5 plants of each cultivar in both treatments i.e., water logging and control in the field.

\section{Ginning outturn percentage}

It is defined as lint percentage in grams from the given sample. Seed cotton samples from five plants of each genotype, water logging and control fields were taken, weighed and ginned with a single roller machine. Ginning outturn percentage was calculated by simple percentage method. 


\section{Fiber quality parameter measurements}

The staple length, fibre fineness and fibre strength of the same specimens, which were collected already for ginning outturn percentage, were tested using High volume instrument (HVI) Spectrum-I Uster USA.

\section{Chlorophyll estimation (chlorophyll $\mathrm{a}, \mathrm{b}$ and $\mathrm{a} / \mathrm{b}$ )}

Chlorophyll $\mathrm{a}$ and $\mathrm{b}$ were determined by the method described by Witham et al. (1971). One gram of fresh leaves from each cultivar was obtained and grinded in porcelain mortar with $40 \mathrm{~mL}$ of $80 \%$ acetone. The supernatant liquid was filtered through a Buchner funnel which fitted with a Whatman \# 40 filter paper, and the filtered material was collected in $100 \mathrm{~mL}$ graduated cylinder. Triturating of sample was repeated with successive $30 \mathrm{~mL}$ portions of $80 \%$ acetone until all the chlorophylls were extracted. The extracted materials were filtered up to $100 \mathrm{~mL}$ with $80 \%$ acetone thoroughly mixing and used to determine chlorophyll contents spectrophotometrically at the appropriate wave lengths. The chlorophyll concentration was calculated by using the following formulae:

$$
\begin{aligned}
& \text { i) chl.a concentration }\left(\mathrm{mg} \cdot \mathrm{g}^{-1}\right)=(12.7 * D 633-2.69 * D 645) * V * W / 1000 \\
& \text { ii) chl.b concentration }\left(\mathrm{mg} \cdot \mathrm{g}^{-1}\right)=(22.9 * D 645-4.68 * D 663) * V * W / 1000 \\
& \text { iii) Chl.a/bratio = concentration of chl.a/concentration of chl.b. }
\end{aligned}
$$

\section{Chlorophyll content measurement}

Chlorophyll content was measured every 3 days interval using a portable (Minolta Chlorophyll Meter SPAD-502, Japan). The average of sextuplicate readings was recorded at each third upper expanded leaflet and data was analyzed using ANOVA to find out differences.

\section{Total soluble proteins estimation}

Total soluble proteins were estimated as described by Lowry et al. (1951). $0.2 \mathrm{~g}$ of fresh leaf material was taken, homogenized in $4 \mathrm{~mL}$ of sodium phosphate buffer solution ( $\mathrm{pH} \mathrm{7)}$ and centrifuged. $0.2 \mathrm{~mL}$ of sample extraction was taken in different culture tubes and the volume of each made up to $2.0 \mathrm{~mL}$ with distilled water. $2.0 \mathrm{~mL}$ of appropriate reagent was added in all tubes. All the tubes were mixed thoroughly and allowed to stand for $10 \mathrm{~min}$ at room temperature. The optical densities were read at $620 \mathrm{~nm}$ using spectrophotometer (Hitachi, U-2000, Japan). Total soluble proteins were estimated according to the following formula:

$$
\begin{aligned}
& \text { Total soluble proteins }\left(\mathrm{mg} \cdot \mathrm{g}^{-1} \text { fresh wt. }\right) \\
& =\frac{\text { Reading of sample } * \text { Volume of sample } * \text { Dilution factor }}{\text { Weight of fresh tissue } * 1000}
\end{aligned}
$$

\section{Estimation of total free amino acids}

Total free amino acids determined following Van Slyke et al. (1943). For the estimation of total free amino acids, $1 \mathrm{~mL}$ of each sample extraction as in case of protein estimation was taken in culture tube and $1 \mathrm{~mL}$ of $10 \%$ pyridine and $1 \mathrm{~mL}$ of $2 \%$ ninhydrin solution were added into each test tube. After that the tubes were heated in water bath for about $30 \mathrm{~min}$. Then the contents of each tube made to $50 \mathrm{~mL}$ with distilled water. Theoptical densities of these colored solutions were read at $570 \mathrm{~nm}$ using spectrophotometer (Hitachi U- 2000, Japan) and free amino acids were calculated as follows.

Total free aminos $\left(\mathrm{mg} \cdot \mathrm{g}^{-1}\right.$ fresh $w t$.

$=\frac{\text { Reading of sample } * \text { Volume of sample } * \text { Dilution factor }}{\text { Weight of fresh tissue } * 1000}$

\section{Statistical analysis of the data}

The data for fresh and dry matter, mineral nutrients and physiological parameters were subjected to analysis of variance using "COSTAT" computer package (Cohort Software, Berkeley, California). Since there was a marked inhibitory effect of iron treatment, in waterlogged condition, on the fresh weight of shoots, the data within each iron treatment were also analyzed separately. The mean values were compared with least significance difference test (LSD) following Snedecor and Cochran (1989).

\section{Results}

Physio-chemical characteristics of the original soil are given in Table 1. ANOVA for plant height, seed cotton yield and ginning outturn (\%) traits depicted significant differences which were observed among all genotypes in all these attributes (Table 2). The means for plant height, seed cotton yield and ginning outturn of all cotton cultivars were significantly reduced due to imposition of flooding (Table 3).

\section{Plant height}

The response of cultivars to waterlogging with respect to plant height showed that the cultivar, MNH-564, had significantly higher plant height than other cultivars under waterlogged conditions. Waterlogging sensitive LRA-5166 and CEDIX had considerable lower value of plant height under waterlogged conditions than other cultivars (Table 3 ).

\section{Seed cotton yield}

Regarding seed cotton yield, all genotypes showed significant reduction in seed cotton yield. MNH-786, $\mathrm{H}-142$ had higher value $(95.667,88.333)$ amongst tolerant and sensitive category, respectively, while the lower values exhibited by the genotypes CIM-573, CEDIX 
Table 1 Physico-chemical characteristics of the original soil before and after conducting the experiment (control and flooded) during 2011-12

\begin{tabular}{llr}
\hline Characteristics & Control & Flooding \\
\hline Electrical conductivity $(E C e)$ of the soil saturated paste $/\left(\mathrm{mS} \cdot \mathrm{cm}^{-1}\right)$ & $2.53 \pm 0.8$ & $2.42 \pm 0.48$ \\
pH of soil saturated paste & $7.65 \pm 0.75$ & $7.6 \pm 0.36$ \\
Textural class & Loam & Loam \\
Saturation percentage $/ \%$ & $36.3 \pm 0.8$ & $36.0 \pm 0.7$ \\
\hline
\end{tabular}

(69.667, 24.333) from the tolerant and sensitive group, respectively (Table 3 ).

\section{Ginning outturn}

A significant reduction in ginning outturn was observed due to waterlogging. MNH-564 had significantly higher ginning out turn than all other cultivars under flooding including tolerant as well as sensitive group (Table 3).

\section{Analysis of variance for fiber traits}

The results of analysis of variance for fiber traits like staple length, fineness and strength revealed significant variation for all the genotypes. The results for water logging and interaction between genotypes and water logging were significant for all the fiber traits except for interaction between genotypes and water logging which revealed non-significant estimates for staple length (Table 3).

\section{Fiber length}

The impact of water logging severely affected staple length which is not desirable for ginners and textile owners (Table 4). The mean values of all tolerant and susceptible genotypes declined from control and remained below $28 \mathrm{~mm}$.

\section{Fiber fineness}

Fibre fineness of all the genotypes showed variable results. The values of susceptible genotypes N-Karishma, LRA-5166 and CEDIX showed an increase in fiber fineness which exceeded above 5.0. The increased values of fineness in susceptible genotypes showed that fiber became coarse under stress. However, the values of tolerant genotypes did not show such drastic increase in fiber fineness (Table 4).

\section{Fiber strength}

All eight flooding tolerant and sensitive genotypes suggested decrease in fibre strength. Maximum fibre strength was observed in waterlogging tolerant cultivars FH-114 and MNH-564 (33.49, 33.20), respectively. But under sensitive group $\mathrm{H}-142$ got the highest value then N-KRISHMA (34.87, 31.39), respectively (Table 4).

\section{Chlorophyll $\mathrm{a}, \mathrm{b}$ contents and $\mathrm{a} / \mathrm{b}$ ratio}

Chlorophyll a, b contents and chl a/b ratio of ANOVA, for these traits publicized significant differences for genotypes, waterlogging/hypoxia and interaction between genotypes and waterlogging. Imposition of waterlogging for 2 weeks on eight cultivars of cotton caused a significant reduction in chlorophyll a, b contents and chlorophyll a/b ratio (Table 5). Two waterlogging tolerant cultivars CIM-573 and MNH-564 (1.664, 1.551) and water logging sensitive, N-KRISHMA, CEDIX (1.259, 1.063) had significantly higher chlorophyll a than other cultivars under both normal and waterlogged conditions. On the contrary, the values of chlorophyll b were higher in waterlogging tolerant cultivar MNH-564 (1.073) then FH-114, (0.929) but hypoxia sensitive genotypes N-KRISHMA and H-142 (0.671, 0.511) had

Table 2 Mean squares from analysis of variance for plant height, seed cotton yield/plant and ginning outturn of eight cotton genotypes/strains/accessions grown under short term hypoxia conditions

\begin{tabular}{|c|c|c|c|c|c|c|c|}
\hline Sources of variations & $d f$ & Plant height /cm & $\begin{array}{l}\text { Seed cotton yield per } \\
\text { plant }\end{array}$ & $\begin{array}{l}\text { Ginning out } \\
\text { turn } / \%\end{array}$ & Staple length /mm & $\begin{array}{l}\text { Fibre Fineness / } \\
\left(\mu \mathrm{g} \cdot \mathrm{inch}^{-1}\right)\end{array}$ & $\begin{array}{l}\text { Fibre Strength / } \\
\left(\mathrm{cN} \cdot \operatorname{tex}^{-1}\right)\end{array}$ \\
\hline Replications & 2 & 2.438 & $3.771 \mathrm{~ns}$ & $0.079 \mathrm{~ns}$ & $0.013 \mathrm{~ns}$ & $0.033 \mathrm{~ns}$ & $1.396 \mathrm{~ns}$ \\
\hline $\begin{array}{l}\text { Genotypes/accession/ } \\
\text { cultivars }\end{array}$ & 7 & $6696.178^{*}$ & $1043.798^{* * *}$ & $45.588^{* * *}$ & $10.978^{* * *}$ & $0.377^{* * *}$ & $152.639^{* * *}$ \\
\hline Waterlogging (WtI.) & 1 & $2380.023^{* *}$ & $2920.475^{* * *}$ & $8.755^{* * *}$ & $15.755^{* * *}$ & $0.13^{* *}$ & $25.521^{* * *}$ \\
\hline Interaction (Gen. × Wtl.) & 7 & $215.512^{* *}$ & $109.321^{* * *}$ & $0.760^{* * *}$ & $0.199 \mathrm{~ns}$ & $0.033^{*}$ & $3.521^{* * *}$ \\
\hline Error & 30 & 9.749 & 5.193 & 0.141 & 0.092 & 0.013 & 0.68 \\
\hline LSD at 0.05 & & 1.676 & 1.224 & 0.202 & 0.163 & 0.055 & 0.044 \\
\hline
\end{tabular}

ns Non significant

${ }^{*}=P \leq(0.05),{ }^{* *}=P \leq(0.01),{ }^{* * *}=P \leq(0.001)$ significant, respectively 
Table 3 Means for Plant height, seed cotton yield and ginning outturn of different genotypes/strains/cultivars grown under normal soil at flowering stage under hypoxia conditions

\begin{tabular}{|c|c|c|c|c|c|c|c|c|}
\hline & \multicolumn{8}{|c|}{ Genotypes/strains/accessions/cultivars } \\
\hline & MNH-564 & $\mathrm{FH}-114$ & MNH-786 & CIM-573 & N-KRISHMA & LRA 5166 & CEDIX & $\mathrm{H}-142$ \\
\hline \multicolumn{9}{|l|}{ Plant height /cm } \\
\hline Control & $140.3 \pm 2.5$ & $92.3 \pm 1.47$ & $115.67 \pm 1.08$ & $128.7 \pm 2.95$ & $143.67 \pm 2.16$ & $55.3 \pm 2.274$ & $51.0 \pm 1.414$ & $126.67 \pm 1.78$ \\
\hline Waterlogging/Hypoxia & $127.0 \pm 1.4$ & $81.0 \pm 3.34$ & $97.3 \pm 1.08$ & $95.3 \pm 2.27$ & $114.67 \pm 2.86$ & $47.0 \pm 1.414$ & $44.0 \pm 1.414$ & $114.67 \pm 1.47$ \\
\hline \multicolumn{9}{|c|}{ LSD (0.05) Control $\times$ Waterlogging $=1.676$} \\
\hline \multicolumn{9}{|l|}{ Seed cotton yield /g } \\
\hline Control & $176.3 \pm 1.08$ & $145.0 \pm 0.7$ & $163.2 \pm 1.08$ & $97.33 \pm 1.08$ & $78.33 \pm 1.47$ & $44.0 \pm 1.14$ & $36.67 \pm 1.47$ & $153.67 \pm 1.87$ \\
\hline Waterlogging/Hypoxia & $89.0 \pm 1.24$ & $71.0 \pm 1.12$ & $95.67 \pm 1.78$ & $69.67 \pm 1.47$ & $51.67 \pm 1.78$ & $37.0 \pm 0.707$ & $24.33 \pm 0.81$ & $88.33 \pm 1.78$ \\
\hline \multicolumn{9}{|c|}{ LSD (0.05) Control $\times$ Waterlogging $=1.224$} \\
\hline \multicolumn{9}{|l|}{ Ginning outturn $/ \%$} \\
\hline Control & $41.2 \pm 0.18$ & $38.5 \pm 0.35$ & $39.67 \pm 0.30$ & $36.5 \pm 0.354$ & $36.67 \pm 0.22$ & $34.10 \pm 0.26$ & $37.43 \pm 0.29$ & $38.67 \pm 0.21$ \\
\hline Waterlogging/Hypoxia & $40.4 \pm 0.14$ & $37.9 \pm 0.25$ & $37.23 \pm 0.35$ & $35.9 \pm 0.255$ & $35.20 \pm 0.14$ & $33.23 \pm 0.18$ & $32.23 \pm 0.29$ & $37.93 \pm 0.21$ \\
\hline \multicolumn{9}{|c|}{ LSD (0.05) Control $\times$ Waterlogging $=0.202$} \\
\hline
\end{tabular}

significantly higher values than rest of the accessions. Chlorophyll a/b ratio was markedly higher in waterlogging tolerant cultivars CIM-573 and MNH-786 (2.087 and 1.483), and waterlogging sensitive cultivars CEDIX and LRA-5166 (3.231, 2.170) got greater values comparing with other cultivars under waterlogged conditions.

Total free amino acids, total soluble proteins and proline Analysis of variance (ANOVA), for total free amino acids, total soluble proteins and proline, characters revealed significant differences for genotypes, waterlogging/hypoxia and interaction between genotypes and waterlogging and showed non-significant differences for replications. There was a significant reduction in total free amino acids in all genotypes/cultivars due to waterlogging (Table 6). Free amino acid content was significantly higher in two waterlogging sensitive cultivars, CEDIX and N-KRISHMA than other cultivars under both non-waterlogged and waterlogged conditions. Waterlogging tolerant genotype $\mathrm{FH}-114$ and waterlogging sensitive $\mathrm{H}-142$ were much lower in free amino acid content of all genotypes under both control and waterlogged conditions.

\section{Total soluble proteins}

Waterlogging caused a significant reduction in shoot soluble proteins in MNH-564, FH-114, and LRA-5166

Table 4 Staple length, fibre fineness/micronaire and fibre strength of eight cotton genotypes/strains/cultivars grown in normal soil at flowering stage under short term hypoxia conditions

\begin{tabular}{|c|c|c|c|c|c|c|c|c|}
\hline & \multicolumn{8}{|c|}{ Genotypes/strains/accessions/cultivars } \\
\hline & $\mathrm{MNH}-564$ & $\mathrm{FH}-114$ & MNH-786 & CIM-573 & N-KRISHMA & LRA 5166 & CEDIX & $\mathrm{H}-142$ \\
\hline \multicolumn{9}{|l|}{ Staple length /mm } \\
\hline Control & $28.3 \pm 0.22$ & $29.3 \pm 0.187$ & $28.30 \pm 0.41$ & $28.50 \pm 0.07$ & $26.53 \pm 0.04$ & $26.13 \pm 0.21$ & $25.23 \pm 0.27$ & $28.67 \pm 0.14$ \\
\hline Waterlogging/Hypoxia & $27.3 \pm 0.21$ & $27.67 \pm 0.21$ & $27.33 \pm 0.08$ & $27.03 \pm 0.34$ & $25.93 \pm 0.08$ & $24.73 \pm 0.33$ & $24.53 \pm 0.04$ & $27.40 \pm 0.141$ \\
\hline \multicolumn{9}{|c|}{ LSD (0.05) Control $\times$ Waterlogging $=0.163$} \\
\hline \multicolumn{9}{|l|}{ Fibre fineness $/\left(\mu \mathrm{g} \cdot \mathrm{inch}^{-1}\right)$} \\
\hline Control & $4.86 \pm 0.07$ & $4.76 \pm 0.04$ & $4.63 \pm 0.108$ & $4.67 \pm 0.08$ & $4.97 \pm 0.04$ & $4.83 \pm 0.041$ & $5.12 \pm 0.08$ & $4.60 \pm 0.071$ \\
\hline Waterlogging/Hypoxia & $4.80 \pm 0.07$ & $4.73 \pm 0.041$ & $4.33 \pm 0.081$ & $4.17 \pm 0.04$ & $5.10 \pm 0.122$ & $5.20 \pm 0.122$ & $5.267 \pm 0.08$ & $4.667 \pm 0.04$ \\
\hline \multicolumn{9}{|c|}{ LSD (0.05) Control $\times$ Waterlogging $=0.055$} \\
\hline \multicolumn{9}{|l|}{ Fibre strength /(cN.tex $\left.{ }^{-1}\right)$} \\
\hline Control & $36.67 \pm 0.41$ & $34.87 \pm 0.41$ & $35.41 \pm 0.41$ & $34.36 \pm 0.38$ & $33.57 \pm 0.31$ & $27.5 \pm 0.307$ & $28.42 \pm 0.41$ & $35.52 \pm 0.51$ \\
\hline Waterlogging / Hypoxia & $33.2 \pm 0.41$ & $33.49 \pm 0.41$ & $32.4 \pm 0.41$ & $32.71 \pm 0.43$ & $31.39 \pm 0.41$ & $26.87 \pm 0.41$ & $28.03 \pm 0.41$ & $34.87 \pm 0.5$ \\
\hline \multicolumn{9}{|c|}{ LSD (0.05) Control $\times$ Waterlogging $=0.044$} \\
\hline
\end{tabular}


Table 5 Chlorophyll a, b contents and chl a/b of eight cotton genotypes/ strains/cultivars grown in normal soil at flowering stage when subjected to short-term hypoxia conditions

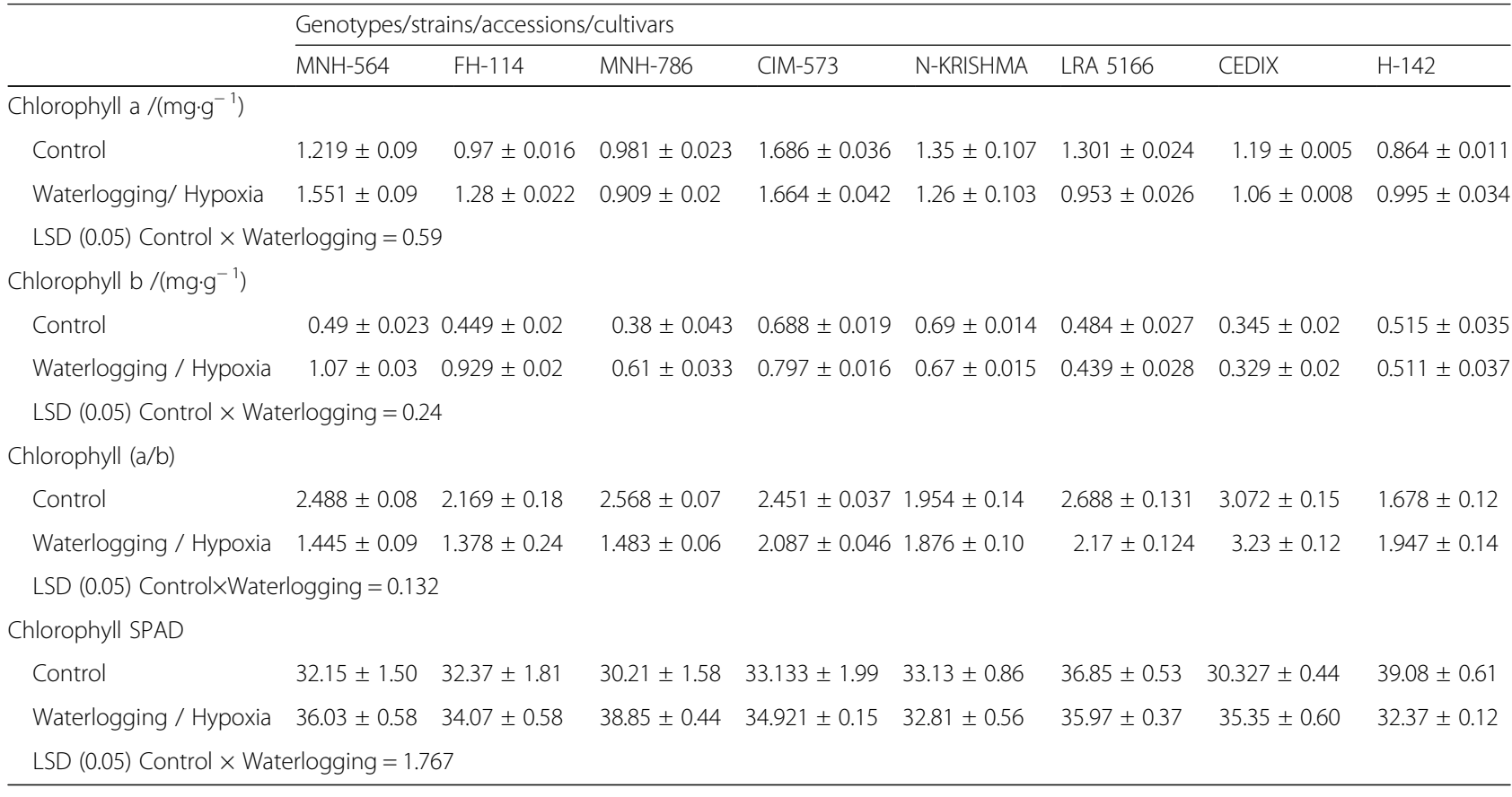

whereas conversely it caused a significant increased in this biochemical attribute in MNH-786, CIM-573 and H-142. Overall, LRA-5166 was the highest in shoot soluble proteins content of all the cultivars under both non-waterlogged and waterlogged conditions (Table 6).

\section{Proline estimation}

Waterlogging caused a significant increase in shoot proline in MNH-564, FH-114, N-KRISHMA, CEDIX, and $\mathrm{H}-142$, whereas in the rest of genotypes there was no significant effect of waterlogging except LRA-5166 in which there was a significant decrease in shoot proline content (Table 6).

\section{Discussions}

In the present study, data for seed cotton yield and yield components clearly slowed that of the four waterlogging tolerant cultivars, only $\mathrm{MNH}-564$ and $\mathrm{FH}-114$ were found to be tolerant as they both excelled other lines in seed cotton yield and yield components under

Table 6 Total free amino acid, total soluble proteins and proline fresh shoot of eight cotton genotypes/strains/cultivars grown in normal soil at flowering stage when subjected to short-term hypoxia condition

\begin{tabular}{|c|c|c|c|c|c|c|c|c|}
\hline & \multicolumn{8}{|c|}{ Genotypes/strains/accessions/cultivars } \\
\hline & $\mathrm{MNH}-564$ & $\mathrm{FH}-114$ & MNH-786 & CIM-573 & N-KRISHMA & LRA 5166 & CEDIX & $\mathrm{H}-142$ \\
\hline \multicolumn{9}{|c|}{ Total free amino acid $/\left(\mathrm{mg} \cdot \mathrm{g}^{-1}\right)$} \\
\hline Control & $6.031 \pm 0.306$ & $5.451 \pm 0.14$ & $6.414 \pm 0.14$ & $6.221 \pm 0.451$ & $9.029 \pm 0.29$ & $7.589 \pm 0.38$ & $10.27 \pm 0.16$ & $5.675 \pm 0.19$ \\
\hline Waterlogging/Hypoxia & $6.115 \pm 0.29$ & $5.643 \pm 0.17$ & $6.419 \pm 0.19$ & $6.897 \pm 0.384$ & $8.518 \pm 0.28$ & $6.817 \pm 0.40$ & $8.825 \pm 0.25$ & $5.328 \pm 0.16$ \\
\hline \multicolumn{9}{|c|}{ LSD (0.05) Control $\times$ Waterlogging $=0.202$} \\
\hline \multicolumn{9}{|c|}{ Total soluble protein $/\left(\mathrm{mg} \cdot \mathrm{g}^{-1}\right)$} \\
\hline Control & $5.53 \pm 0.068$ & $6.37 \pm 0.047$ & $6.841 \pm 0.05$ & $6.874 \pm 0.093$ & $6.851 \pm 0.13$ & $8.34 \pm 0.22$ & $6.759 \pm 0.22$ & $5.66 \pm 0.127$ \\
\hline Waterlogging/Hypoxia & $4.94 \pm 0.06$ & $5.55 \pm 0.085$ & $6.604 \pm 0.08$ & $6.695 \pm 0.127$ & $6.767 \pm 0.15$ & $8.24 \pm 0.157$ & $6.805 \pm 0.19$ & $6.79 \pm 0.08$ \\
\hline \multicolumn{9}{|c|}{ LSD (0.05) Control $\times$ Waterlogging $=0.151$} \\
\hline \multicolumn{9}{|l|}{ Proline $/\left(m g \cdot g^{-1}\right)$} \\
\hline Control & $6.112 \pm 0.34$ & $6.657 \pm 0.29$ & $7.37 \pm 0.359$ & $9.959 \pm 0.410$ & $5.82 \pm 0.012$ & $8.65 \pm 0.144$ & $9.17 \pm 0.06$ & $6.33 \pm 0.32$ \\
\hline Waterlogging/Hypoxia & $6.907 \pm 0.34$ & $8.337 \pm 0.32$ & $7.47 \pm 0.37$ & $10.107 \pm 0.47$ & $6.71 \pm 0.017$ & $7.70 \pm 0.16$ & $9.99 \pm 0.049$ & $9.87 \pm 0.294$ \\
\hline \multicolumn{9}{|c|}{ LSD (0.05) Control $\times$ Waterlogging $=0.305$} \\
\hline
\end{tabular}


waterlogged conditions. Other two waterlogging tolerant cultivars MNH-786 and CIM-573 were as good as all four waterlogging sensitive cultivars in all yield attributes under waterlogged conditions. From such a differential response of the four waterlogging tolerant cultivars to flooding, it is evident that selection made in the first experiment on the basis of just survival rate is partially effective. This can be explained in view of the argument of Zhou (2010), that selection based on yield may be confounded because of the possibility that tolerance and recovery mechanisms only partly contributed to the crop yield after the waterlogging stress was terminated. Moreover, Setter and Waters (2003) suggested that it is possible that a waterlogging tolerant variety may possess a mechanism of tolerance associated with escaping from anaerobic conditions through dormancy or slow growth during a stress period, and have a rapid recovery following stress. It is therefore, evaluation of flooding tolerance in germplasm should be based on physiological and biochemical characteristics (Zhou 2010). This argument can be supported by the fact that a prior knowledge of the effectiveness of a selection criterion or criteria to be used in a breeding program is essential, otherwise chances of improvement in any traits through selection are very low (Parelle et al. 2010; Zhou 2010).

Waterlogging affects numerous physiological and metabolic processes within plants leading to reduction in growth and yield (Shabala et al. 2014). Degree of flooding stress tolerance can also be evaluated using physiological and biochemical traits contributing to flooding tolerance (Adaptive traits). However, physiological mechanisms of degree of tolerance to waterlogging and hypoxia are still not fully understood despite accumulating information (Parolin 2009).

Although chlorophyll a, b and chlorophyll $\mathrm{a} / \mathrm{b}$ ratios of all eight cotton cultivars decreased due to waterlogging, the difference among the cultivars with respect to these pigments was not consistent. These results are not in agreement with those of Talbot et al. (1987) in which they found a marked reduction in chlorophyll contents of the waterlogging sensitive Salix caprea compared with the waterlogging tolerant S. cinerea. Similarly, Ashraf and Chishti (1993) reported that the reduction in chlorophyll content was more pronounced in waterlogging sensitive accessions of lentil compared with the waterlogging tolerant ones.

The responses of waterlogging tolerant and waterlogging sensitive cultivars of cotton for leaf soluble proteins, free amino acids or proline were not consistent, and it was not possible to discriminate between the cultivars using these biochemical attributes. These results are contradictory to the findings of Drew and Sisworo (1979) in which they reported that inhibition in $\mathrm{N}$ uptake in plants with redistribution of
$\mathrm{N}$ from old leaves to young leaves under flooding contributes to a reduction in the total plant $\mathrm{N}$ content which thereby lowered the plant protein content. These results do not agree with the earlier findings of Ashraf and Mehmood (1990) in which they observed a decrease in soluble protein content in the waterlogging sensitive (Brassica napus L.), but an increase in that of the waterlogging tolerant Brassica juncea.

\section{Conclusion}

Yield and physiological traits under hypoxia showed abnormal values than usual with significant reductions. However, the genotypes like MNH-786 showed better performance in terms of yield and two cultivars i.e., CIM-573 and MNH-564, exhibited significantly higher chlorophyll a than other cultivars under both conditions. The values of free amino acids are on the higher side in all the genotypes which were not desirable. The genotypes exploited in this experiment may further be exploited in devising strategy to develop hypoxia tolerant cultivars.

\section{Funding}

The research was not funded by any organization. Instead Hussain A bear all the expenses of research. The research work was part of PhD research of Hussain A who solely managed the experiment.

\section{Availability of data and materials \\ Data supporting the finding will be provided on demand. For demand of data any one can contact Hussain A and Farooq J through email and institutional addresses.}

\section{Authors' contributions}

Hussain A designed the study for his PhD research and collected the data. Farooq J helped Hussain A in data collection and analysis of data, and also helped in the collection of literature and write up of the manuscript. Ahmad $\mathrm{S}$ helped in the initial reviewing process of the manuscript. Ahmad $\mathrm{S}$ and Mahmood A read out every section of the manuscript before final submission. Zafar UZ and Athar HUR were the members of supervisory committee of Hussain A, they both provided guidelines in designing and layout of the experiment. They also reviewed the article and gave valuable suggestions for its improvement. Sadiq MA helped in interpretation of results and provided the germplasm along with their traits, and he also took part in literature collection and formatting of the manuscript. All authors read and approved the final manuscript.

Ethics approval and consent to participate Not Applicable.

\section{Consent for publication}

Not Applicable.

Competing interests

The authors declare that they have no competing interests.

\section{Publisher's Note}

Springer Nature remains neutral with regard to jurisdictional claims in published maps and institutional affiliations.

\section{Author details}

${ }^{1}$ Cotton Research Station, Bahawalpur, Pakistan. ${ }^{2}$ Cotton Research Station, Ayub Agricultural Research Station, Faisalabad, Pakistan. ${ }^{3}$ Cotton Research Institute, Multan, Pakistan. ${ }^{4}$ Ayub Agricultural Research Institute, Faisalabad, Pakistan. ${ }^{5}$ Institute of Pure and Applied Biology, Bahauddin Zakariya University, Multan, Pakistan. 
Received: 24 March 2018 Accepted: 13 August 2018

Published online: 28 August 2018

\section{References}

Ashraf M, Chishti SN. Waterlogging tolerance of some accessions of lentil (Lensculinaris Medic.). Trop Agric. 1993;70:60-7.

Ashraf M, Mehmood S. Effects of waterlogging on growth and some physiological parameters of four Brassica species. Plant and Soil. 1990;121: 203-9. https://doi.org/10.1007/BF00012313 .

Bailey-Serres J, Voesenek LACJ. Flooding stress: acclimations and genetic diversity. Ann Rev PI Biol. 2008:59:313-39. https://doi.org/10.1146/annurev.arplant.59. 032607.092752.

Blom CWPM, Voesenek LACJ. Flooding the survivals strategies of plants. Trends Ecol Evol. 1996;11:290-5. https://doi.org/10.1016/0169-5347(96)10034-3

Boru G, Ginkel MV, Kronstad WE, Boersma L. Expression and inheritance of tolerance to waterlogging stress in wheat. Euphytica. 2001;117(2):91-8. https://doi.org/10.1023/A:1003929803920

Cai SB, Cao Y, Fang XW. Studies on the variability and combining ability of waterlogging tolerance in common wheat. Jiangsu J Agric Sci. 1996;12:1-5.

Dodd K, Guppy CN, Lockwood PV, Rochester IJ. Impact of waterlogging on the nutrition of cotton (Gossypium hirsutum L.) produced in sodic soils. Crop and Pasture Sci. 2013;64:816-24.

Drew MC, Sisworo EJ. The development of waterlogging damage in young barley plants in relation to plant nutrient status and changes in soil properties. New Phytologist. 1979;82:301-14. https://doi.org/10.1111/j. 1469-8137.1979.tb02656.X

Hamachi Y, Yoshino M, Furusho M, Yoshida T. Index of screening for wet endurance in malting barley. Japan J Breed. 1990;40:361-6.

Hussain A, Zafar ZU, Athar HUR. Flooding tolerance in cotton (Gossypium hirsutum L.) at early vegetative and reproductive growth stages. Pak J Bot. 2014;46(3):1001-9.

Lowry OH, Rosebrough NJ, Farr AL, Randall RJ. Protein measurement with the Folin phenol reagent. J Biol Chem. 1951;193:265-75.

Pang JY, Zhou MX, Mendham N, et al. Growth and physiological responses of six barley genotypes to waterlogging and subsequent recovery. Aust J Agric Res. 2004;55:895-906. https://doi.org/10.1071/AR03097 .

Parelle J, Dreyer E, Brendel O. Genetic variability and determinism of adaptation of plants to soil waterlogging. In: Mancuso S, Shabala S, editors. Waterlogging signaling and tolerance in plants. Heidelberg: SpringerVerlag; 2010. p. 241-65.

Parolin P. Submerged in darkness: adaptations to prolonged submergence by woody species of the Amazonian flood plains. Ann Bot. 2009;103(2):359-76. https://doi.org/10.1093/aob/men216

Salman M, Khan AA, Rana IA, et al. Genetic architecture of relative cell injury and some yield related parameters in Gossypium hirsutum L. Turk J Field Crops. 2016;21(2):246-53.

Setter TL, Waters I. Review of prospects for germplasm improvement for waterlogging tolerance in wheat, barley and oats. Plant and Soil. 2003;253:1-34. https:/doi.org/ 10.1023/A:1024573305997

Shabala S, Shabala L, Barcelo J, Poschenrieder C. Membrane transporters mediating root signalling and adaptive responses to oxygen deprivation and soil flooding. Plant Cell Environ. 2014;37(10):2216-33.

Shaw RE, Meyer WS, McNeill A, Tyerman SD. Waterlogging in Australian agricultural landscapes: a review of plant responses and crop models. Crop \& Pasture Science. 2013;64:549-62. https://doi.org/10.1071/CP13080

italicSnedecor GW, Cochran WG. Statistical methods, 8th ed. Ames: Iowa State University Press; 1989

Talbot RJ, Etherington JR, Bryant JA. Comparative studies of plant growth and distribution in relation to waterlogging. XIII. Growth, photosynthetic capacity and metal ion uptake in salixcaprea and S. cinerea ssp. Oleifolia. New Phytologist. 1987;105:563-74. https://doi.org/10.1111/j.1469-8137.1987.tb00894.x

Van Slyke DD, Phillips RA, Hamilton PB, et al. Glutamine as a source material of urinary ammonia. J Biot Chem. 1943;150:481-2.

Voesenek LACJ, Bailey-Serres J. Flooding tolerance: $\mathrm{O}_{2}$ sensing and survival strategies. Curr Opin Plant Biol. 2013;16:1-7. https://doi.org/10.1016/j.pbi. 2013.06.008

Witham FH, Blaydes BF, Devlin RM. Experiments in plant physiology. New York: Van Nostrand Reinhold; 1971. p. 167-200.

Zhou MZ. Improvement of plant waterlogging tolerance. In: Mancuso S, Heidelberg SS, editors. Waterlogging signalling and tolerance in plants. Berlin: Springer-Verlag; 2010. p. 267-85.

Ready to submit your research? Choose BMC and benefit from:

- fast, convenient online submission

- thorough peer review by experienced researchers in your field

- rapid publication on acceptance

- support for research data, including large and complex data types

- gold Open Access which fosters wider collaboration and increased citations

- maximum visibility for your research: over $100 \mathrm{M}$ website views per year

At $\mathrm{BMC}$, research is always in progress.

Learn more biomedcentral.com/submissions 